\title{
Two new species of Camellia (Theaceae) from Vietnam
}

\author{
Lieu Thi NGUYEN, Ninh TRAN ${ }^{1}$, Uematsu CHIYOMI, Katayama HIRONORI ${ }^{2}$, \\ Dung Van LUONG ${ }^{3}$, Son Thanh HOANG ${ }^{4 *}$ Ky Danh NGUYEN ${ }^{5}$, \\ Hung Viet NGUYEN ${ }^{5}$ and Toan Canh THAI ${ }^{5}$ \\ Graduate School of Science, Botanical Gardens of Osaka City University, Osaka 558-8585, Japan \\ ${ }^{1}$ Faculty of Biology, VNU University of Science, Hanoi 100000, Vietnam \\ ${ }^{2}$ Food Resources Research and Education Center, Graduate School of Agricultural Science, Kobe University, Kobe 657-8501, Japan \\ ${ }^{3}$ Deparment of Biology, Da Lat University, Dalat 670000, Vietnam \\ ${ }^{4}$ Silviculture Research Institute, Hanoi 100000, Vietnam \\ ${ }^{5}$ Vu Quang National Park, Hatinh 480000, Vietnam
}

(Received 23 January 2018; Revised 11 April 2018; Accepted 1 May 2018)

\begin{abstract}
Two new species of Camellia (Theaceae) are described from Vietnam: Camellia vuquangensis Luong, Tran \& L. T. Nguyen and Camellia hatinhensis Luong, Tran \& L. T. Nguyen. The new taxa were collected from Vu Quang National Park in the center of Vietnam. The new finds are morphologically dissimilar to all known Camellia species. Recent Camellia discoveries have increased the number of species recorded in Vietnam from 50 to 75 , making Vietnam a center of diversity and a crucial area for more research into the diversity and distributions of Camellia.
\end{abstract}

Keywords: Camellia, Ha Tinh, new species, Vietnam, Vu Quang

Camellia is the largest genus of the Theaceae, with an estimated 120 to 300 species (Chang and Bartholomew, 1984; Ming and Bartholomew, 2007). According to Sealy (1958), Chang and Bartholomew (1984), Gao et al. (2005), Ming and Bartholomew (2007), about $80 \%$ of these species are found in China and others are found in Cambodia, Indonesia, Japan, Laos PDR,, Philippines, Thailand, and Vietnam.

In Vietnam, about 50 species of Camellia were recognized prior to the mid-2000's (Ho, 1999; Ninh, 2002). However, in recent years additional species of Camellia have been discovered and described from Vietnam, increasing the total to 75 species and making Vietnam the centre of Camellia diversity (Orel and Wilson, 2010, 2012; Ninh and Dung, 2012, 2013; Orel et al., 2012, 2013, 2014a, 2014b; Luu et al., 2015; Ninh and Ninh, 2015; Dung et al., 2016; Ninh and Dung, 2016).

$\mathrm{Vu}$ Quang National Park with about 1,678 species of vascular plants, 94 species of mammals, 315 species of birds, 58 species of reptiles, and 31 species of amphibians, including many endemic and rare species, have been recorded, indicating that Vu Quang National Park is one of the centers of biodiversity for Vietnam (Vu Quang National Park Management Board, 2014).

During a field trip in 2016 to survey on Camellia in the Vu Quang National Park, we collected two species of Camellia. Careful examination of the morphological characters indicated and more than 300 dried specimens kept in the following herbaria were also examined: VAFS, DLU, $\mathrm{HN}$, VNM as well as digitized plant specimen images available on the web of Muséum National d'Histoire Naturelle (https://science.mnhn.fr/) and Chinese Virtual Herbarium (http://www.cvh.org.cn/) that did not match any described species.

\section{Taxonomic Treatment}

1. Camellia vuquangensis Luong, Tran \& L. T. Nguyen, sp. nov. (Figs. 1, 2).-TYPE: VIETNAM. Ha Tinh province, Vu Quang district, 21 Aug 2017 (fl), Luong Van Dung, Tran

\footnotetext{
*Author for correspondence: hoangsonfsiv@gmail.com
} 



Fig. 1. Camellia vuquangensis Luong, Tran \& L. T. Nguyen. A. Leaf, adaxial surface. B. Venation detail of leaf (abaxial surface). C. Venation of leaf (adaxial surface). D. Flower, lateral view. E. Flower, top view. F. Perules (inner surfaces shown). G. Petals (inner surfaces). H. Stamens. I. Pedicel and gynoecium (other floral parts removed) (drawn by Luong Van Dung). 




Fig. 2. Camellia vuquangensis Luong, Tran \& L. T. Nguyen. A. Branches. B. Flower bud. C. Flower, lateral view. D. Flower, top view.

Ninh, Nguyen Thi Lieu, Do Cong Thuan, Thai Canh Toan, Le Van Toan, Hoang Van Hoan VN.0358 (holotype: DLU, Isotype: VAFS).

Shrub, 3-4 m tall, young branches and leaves light violet and pubescent. Leaves stalked; blade thick and coriaceous, oblong, 12-23 cm long and 4-7 cm wide, glabrous above, hirsute below, the apex acuminate to long caudate, the base auriculate with some teeth, the margins sharply serrulate, the midribs sunken above and protruding below with 17 to 22 pairs of lateral veins, sunken above and protruding below the main leaf surface; the petioles $8-10 \mathrm{~mm}$ long, hirsute. Flowers 1 or 2 , positioned on the terminal or axillary of branches, 8 $9.5 \mathrm{~cm}$ in diameter, shortly pedicellate. Perules 6 or 7 , scale shaped to nearly rounded, $0.4-2.2 \mathrm{~cm}$ high, $0.4-1.6 \mathrm{~cm}$ wide, pubescent on both sides, ciliate margins. Petals 13 or 14 , elliptic, obovate, oblanceolate, entire, light yellow, 2.5$6.0 \mathrm{~cm}$ long, $1.5-2.5 \mathrm{~cm}$ wide, emarginated, glabrous on inner surfaces, pubescent central region of outer surfaces, united 
Table 1. Morphological comparison between $C$. vuquangensis with $C$. dilinhensis.

\begin{tabular}{|c|c|c|}
\hline Characters & Camellia vuquangensis & Camellia dilinhensis \\
\hline Leaf blade shape & Oblong & Oblong elliptic or elliptic, glabrous \\
\hline Leaf size & $12-23 \mathrm{~cm}$ long and $4-7 \mathrm{~cm}$ wide & 16-24.5 cm long, 5.5-9.5 cm wide \\
\hline Leaf apex & Acuminate to long caudate & Acuminate \\
\hline Leaf base & Auriculate with some teeth & Cuneate \\
\hline Petiole & 8-10 mm long, hirsute & $1-1.9 \mathrm{~cm}$ long, glabrous \\
\hline Flowers & 1 or 2 , terminal or axillary & 1 to 3 in each group in axillary \\
\hline Flower diameter $(\mathrm{cm})$ & $8-9.5$ & $3.5-3.7$ \\
\hline Pedicel & Absent & 5-7 mm long, glabrous \\
\hline Petal number & 13 or 14 & 8 or 9 \\
\hline Petal shape & Elliptic, obovate, oblanceolate & Nearly rounded to elliptic \\
\hline Petal size & $2.5-6.0 \mathrm{~cm}$ high, $1.5-2.5 \mathrm{~cm}$ wide & $1.5-1.7 \mathrm{~cm}$ long, $1.2-1.4 \mathrm{~cm}$ wide \\
\hline Petal hairiness & Pubescent on middle outer surfaces & Glabrous on both sides \\
\hline Stamens & 290 stamens, 5 or 6 circles & 350 stamens, 4 or 5 circles \\
\hline Filaments & $3.5-4.5 \mathrm{~cm}$ long, pubescent to $1 / 2$ from the base & 5-9 mm long, glabrous \\
\hline Style & $\begin{array}{c}3 \text {, free to the base, } 1-1.3 \mathrm{~cm} \text { long, pubescent to } 1 / 2 \\
\text { from the base }\end{array}$ & 3 , free to the base, $5 \mathrm{~mm}$ long, pubescent \\
\hline
\end{tabular}

with outermost filaments $0.6-1.8 \mathrm{~cm}$ at the base. Androecium over 290 stamens, in 6 or 7 circles, light yellow, 3.5-4.5 cm long, pubescent to $1 / 2$ from the base, outer filaments united for 2-2.4 $\mathrm{mm}$ from the base and form a short cup. Ovary cylindrical, 3-locular, 5-6 mm long, pubescent; styles 3, free to the base, $1-1.3 \mathrm{~cm}$ long, pubescent to $1 / 2$ from the base. Capsule not seen.

Distribution and phenology: This species was found in the forest of Vu Quang International Park, Vu Quang district, Ha Tinh province, at the elevation of 50-100 m. Blooming season: Spring, August to September.

Etymology: The specific epithet of the new species refers to the location of discovery, Vu Quang National Park, Vietnam.

IUCN Red List category: The Area of Occupancy (AOO) for $C$. vuquangensis is estimated to be less than $1 \mathrm{~km}^{2}$, as extensive surveys in the wider region have not located this species elsewhere. Despite a further search of the area around the type locality, only eight additional mature trees were found. The total known population of the species is fewer than 50 individuals, and it would be qualified as Critically Endangered (CR) under criterion D (IUCN, 2011).

Taxonomic remarks: This species most closely resembles Camellia dilinhensis of sect. Obvoidae Tran et Luong (Ninh and Dung, 2013) as the leaf is elliptic oblong; flowers are yellow and are either solitary or a pair at the ends of branches; ovary 3-locular, cylindrical, pubescent; style 3, free. Thus based on morphological similarity, this species should be assigned to sect. Obvoidae Tran et Luong. The main similarities and differences between Camellia vuquangensis with Camellia dilinhensis are summarized in Table 1.

2. Camellia hatinhensis Luong, Tran \& L. T. Nguyen, $s p$. nov. (Figs. 3, 4).-TYPE: VIETNAM. Ha Tinh province, Vu Quang district, 27 Aug 2017, Luong Van Dung, Tran Ninh, Nguyen Thi Lieu, Do Cong Thuan, Nguyen Viet Hung VN.0354 (holotype, isotype: DLU).

Shrubs or small trees, 4-6 m tall, young branches villous becoming glabrous with age. Leaves stalked; blade thick and coriaceous, oblong, $11-15 \mathrm{~cm}$ long and $3-5 \mathrm{~cm}$ wide, glabrous above, villous below, the apex acuminate to long caudate; the base broadly cuneate or nearly rounded, the midribs sunken above and protruding below main leaf, 10 to 14 pairs of lateral veins sunken above and protruding below the main leaf, the margins serrulate or serrate; petioles 1$1.3 \mathrm{~mm}$ long, villous. Flowers solitary at branch apices, white, $8-9 \mathrm{~cm}$ in diameter, the pedicel absent. Perules 9 or 10 , nearly rounded, $0.4-2.3 \mathrm{~cm}$ high, $0.3-2.1 \mathrm{~cm}$ wide, pubescent on both sides, persistent, margins ciliate. Petals 10 or 11 , elliptical, nearly rounded, obovate, retire, $2.7-4.8 \mathrm{~cm}$ long, $2.3-4.5 \mathrm{~cm}$ wide, pubescent on both sides, united with 


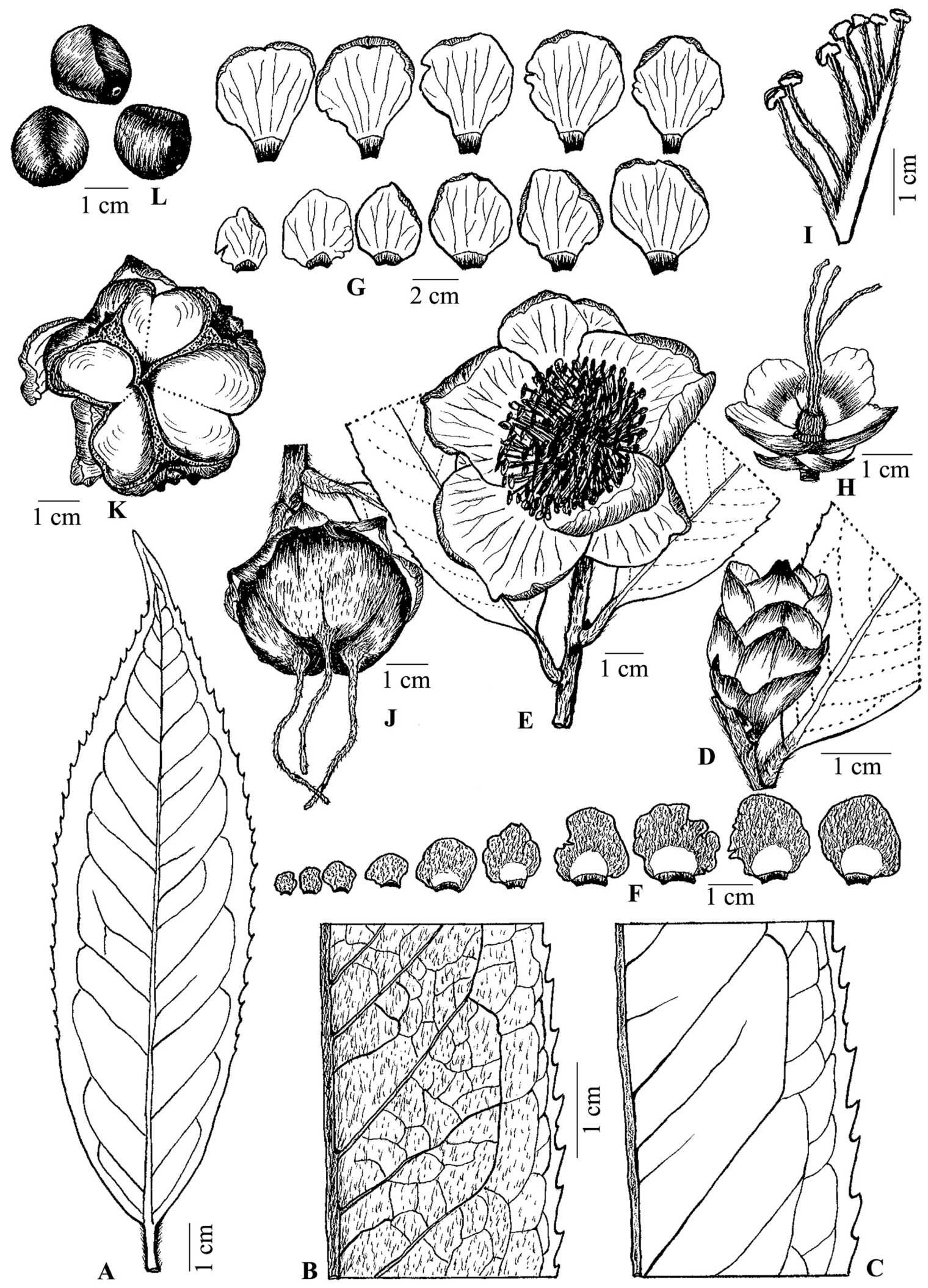

Fig. 3. Camellia hatinhensis Luong, Tran \& L. T. Nguyen. A. Leaf, adaxial surface. B. Venation detail of leaf (abaxial surface). C. Venation of leaf (adaxial surface). D. Flower bud. E. Flower, top view. F. Perules (inner surfaces shown). G. Petals (inner surfaces). H. Perules and gynoecium. I. Stamens. J. Capsule with persisting styles. K. Pericarpa. L. Seeds (drawn by Luong Van Dung). 

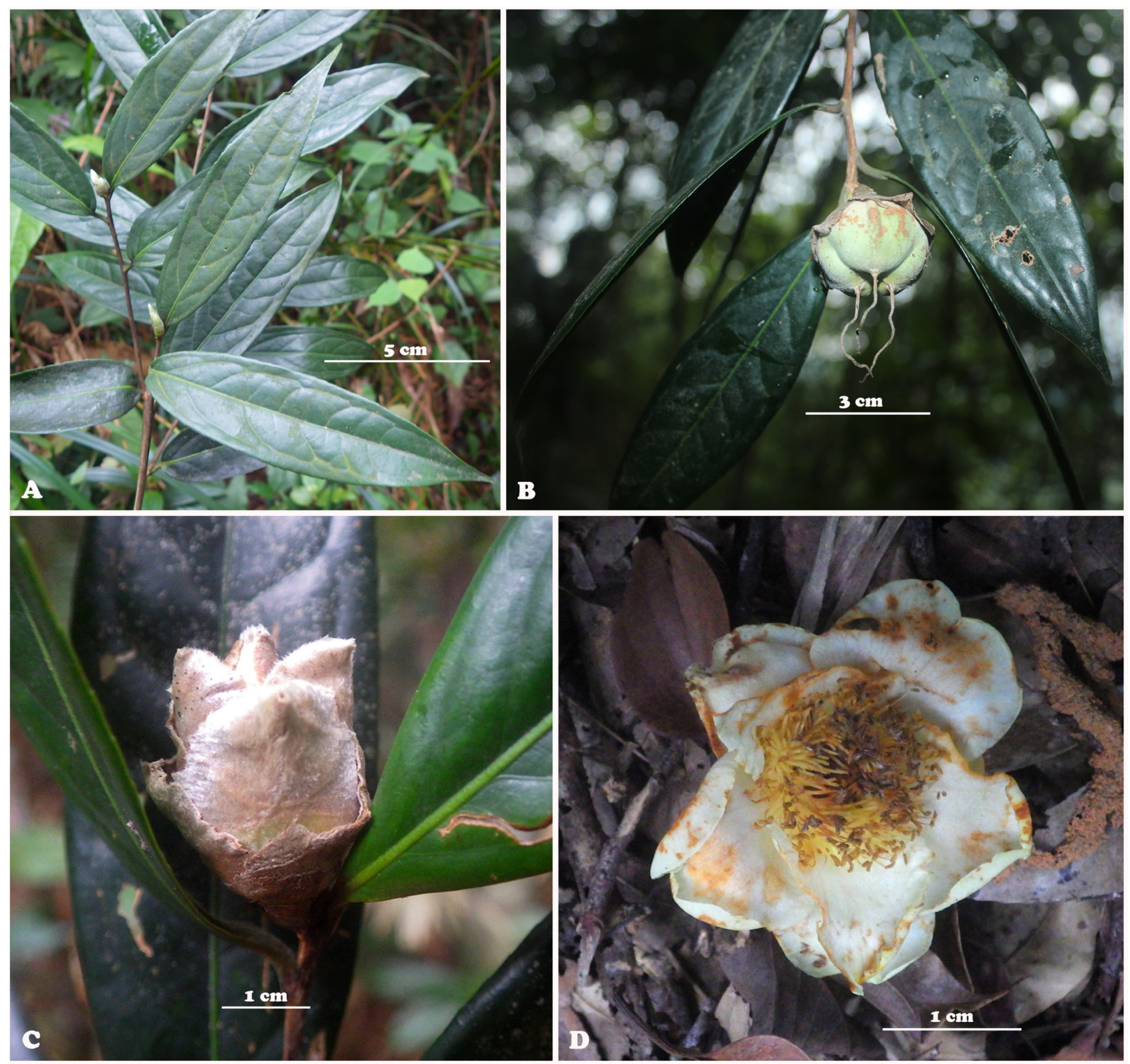

Fig. 4. Camellia hatinhensis Luong, Tran \& L. T. Nguyen. A. Branches. B. Fruit. C. Flower bud. D. Flower.

outermost filaments $0.5-1.3 \mathrm{~cm}$ at the base. Androecium over 300 stamens, in 6 or 7 circles, 3-3.5 cm long, pubescent, outer filaments united from the base and forming a short cup, united $1.3-1.6 \mathrm{~cm}$ at the base. Ovary nearly rounded, 3locular, tomentose, $0.5 \mathrm{~cm}$ long, $0.4 \mathrm{~cm}$ wide; styles 3 , free to the base, $3-3.3 \mathrm{~cm}$ long, tomentose. Fruits globose, pubescent, $3.5-4 \mathrm{~cm}$ in diameter, 3-locular, with 1 or 2 seeds in each locule, columella abortive. Seeds cuneate or semiglobose, $1.6-1.9 \mathrm{~cm}$ high, $1.1-1.4 \mathrm{~cm}$ wide, glabrous.

Distribution and phenology: This species was found in the forest of Vu Quang National Park, Vu Quang district, Ha
Tinh province, at the elevation over $100 \mathrm{~m}$. Flowering: August to September; Fruiting: October to November.

Etymology: The specific epithet of the new species refers to the location of discovery, Ha Tinh province, Vietnam.

IUCN Red List category: The AOO for $C$. hatinhensis is estimated to be less than $1 \mathrm{~km}^{2}$. Despite a further search of the area around the type locality and other forests in the vicinity, only eight additional mature trees were found. The total known population of the species is fewer than 50 individuals, and it would be qualifid as CR under criterion D (IUCN, 2011). 
Table 2. Morphological comparison between C. hatinhensis with C. gauchowensis, C. oleifera, C. sasanqua, and C. vietnamemsis.

\begin{tabular}{|c|c|c|c|c|c|}
\hline Characters & C. hatinhensis & C. gauchowensis & C. oleifera & C. sasanqua & C. vietnamemsis \\
\hline Young shoots & Villous & Villous & Glabrous to villous & Villous & Villous \\
\hline Leaf blade shape & Oblong & Elliptic to mostly obovate & Elliptic to broadly elliptic & Elliptical & Elliptic to ovate, rarely obovate \\
\hline Leaf size & $\begin{array}{l}11-15 \mathrm{~cm} \text { long, } \\
3-5 \mathrm{~cm} \text { wide }\end{array}$ & $\begin{array}{l}6.8-9.0 \mathrm{~cm} \text { long, } \\
2.9-5.0 \mathrm{~cm} \text { wide }\end{array}$ & $\begin{array}{l}4.0-11.7 \mathrm{~cm} \text { long, } \\
1.4-5.1 \mathrm{~cm} \text { wide }\end{array}$ & $\begin{array}{l}2.6-6.3 \mathrm{~cm} \text { long, } \\
0.9-3.2 \mathrm{~cm} \text { wide }\end{array}$ & $\begin{array}{l}5.4-13.1 \mathrm{~cm} \text { long, } \\
2.7-6.7 \mathrm{~cm} \text { wide }\end{array}$ \\
\hline Leaf apex & Acuminate to long caudate & Acute to obtuse or short acuminate & Acute to short acuminate & $\begin{array}{l}\text { Acute or variously acuminate to } \\
\text { occasionally cuspidate }\end{array}$ & Acute to mostly short acuminate \\
\hline Leaf base & $\begin{array}{l}\text { Broadly cuneate or nearly } \\
\text { rounded }\end{array}$ & Cuneate & Cuneate to mostly rounded & Cuneate & Cuneate to mostly rounded \\
\hline Upper surface & Glabrous & Smooth, midrib densely puberulent & $\begin{array}{l}\text { Smooth, midrib moderately } \\
\text { puberulent }\end{array}$ & $\begin{array}{l}\text { Smooth, hirsutulous along the } \\
\text { midrib }\end{array}$ & Smooth, the midrib puberulent \\
\hline Lower surface & Villous & Midrib villous & $\begin{array}{l}\text { Rarely with few hairs, midrib } \\
\text { sparsely villous or glabrous }\end{array}$ & $\begin{array}{l}\text { Smooth, with a few hairs along } \\
\text { the midrib. }\end{array}$ & $\begin{array}{l}\text { Smooth, midrib glabrous to } \\
\text { villous }\end{array}$ \\
\hline Petiole & $1-1.3 \mathrm{~mm}$ long, villous & 5-10 mm long, puberulent & 3-6 mm long, villous & 4-6 mm long, villous & 5-12 mm long, puberulent \\
\hline Flower diameter & $8-9 \mathrm{~cm}$ & $6.0-7.5 \mathrm{~cm}$ & $5.5-7.0 \mathrm{~cm}$ & $5.0-7.6 \mathrm{~cm}$ & $7.5-13.9 \mathrm{~cm}$ \\
\hline Perules & $\begin{array}{l}9 \text { or } 10, \text { persistent, pubescent } \\
\text { on both sides }\end{array}$ & 10 to 12 , deciduous & $\begin{array}{l}\text { 8, deciduous, outside heavily } \\
\text { pubescent, inside glabrous }\end{array}$ & $\begin{array}{l}8 \text { to } 10 \text {, deciduous, more or less } \\
\text { pubescent on the outside, inside } \\
\text { glabrous }\end{array}$ & $\begin{array}{l}9 \text { or } 10, \text { deciduous, outside } \\
\text { pubescent, inside glabrous }\end{array}$ \\
\hline Petal number & 10 or 11 & 7 or 8 & 7 or 8 & 7 or 8 & 8 to 10 \\
\hline Petal shape & $\begin{array}{c}\text { Elliptic, nearly rounded, } \\
\text { obovate, united with outermost } \\
\text { filaments }\end{array}$ & $\begin{array}{l}\text { Obovate, cleft at the tip, nearly free } \\
\text { at the base with little or no fusion to } \\
\text { the staminal column }\end{array}$ & $\begin{array}{l}\text { Obovate to obcordate, cleft at } \\
\text { tip, fused with the staminal } \\
\text { column }\end{array}$ & $\begin{array}{c}\text { Oblanceolate to obovate, cleft at } \\
\text { the tip, petals free }\end{array}$ & $\begin{array}{l}\text { Obcordate, cleft at tip, petals } \\
\text { free }\end{array}$ \\
\hline Petal size & $\begin{array}{l}2.7-4.8 \mathrm{~cm} \text { long, } \\
2.3-4.5 \mathrm{~cm} \text { wide }\end{array}$ & $\begin{array}{l}3.0-3.8 \mathrm{~cm} \text { long, } \\
1.5-2.6 \mathrm{~cm} \text { wide }\end{array}$ & $\begin{array}{l}3.2-3.9 \mathrm{~cm} \text { long, } \\
1.5-2.4 \mathrm{~cm} \text { wide }\end{array}$ & $\begin{array}{l}3.0-3.7 \mathrm{~cm} \text { long, } \\
1.4-2.4 \mathrm{~cm} \text { wide }\end{array}$ & $\begin{array}{l}3.9-7.5 \mathrm{~cm} \text { long, } \\
3.0-4.9 \mathrm{~cm} \text { wide }\end{array}$ \\
\hline Androecium hairiness & Pubescent & Glabrous & Glabrous & Glabrous & Glabrous \\
\hline Androecium length & $3-3.5 \mathrm{~cm}$ & $1.0-1.2 \mathrm{~cm}$ & $1.8 \mathrm{~cm}$ & $1.1-1.6 \mathrm{~cm}$ & $1.2-2.0 \mathrm{~cm}$ \\
\hline Gynoecium length & $3.5-3.8 \mathrm{~cm}$ & $1.0 \mathrm{~cm}$ & $1.2-1.6 \mathrm{~cm}$ & $1.1-1.5 \mathrm{~cm}$ & $1.2-2.0 \mathrm{~cm}$ \\
\hline Style & 3 , tomentose, free to the base & 3 to 5 , glabrous, free at the base & $\begin{array}{c}3 \text { to } 5 \text {, glabrous, fused } 1 / 2 \text { from } \\
\text { the base }\end{array}$ & $\begin{array}{l}3 \text {, glabrous, styles, range from } \\
\text { fused } 1 / 4 ? 2 / 3 \text { from the base }\end{array}$ & $\begin{array}{l}3 \text { to } 5 \text {, glabrous, free or fused up } \\
\text { to } 1 / 2 \text { from the base }\end{array}$ \\
\hline
\end{tabular}


Taxonomic remarks: Camellia hatinhensis possesses some morphological characteristics common to the species $C$. gauchowensis Chang, C. oleifera Abel; C. sasanqua Thunb. and C. vietnamemsis Huang ex $\mathrm{Hu}$ (Gao et al., 2005) belonging to Section Oleifera Hung T. Chang (Chang and Bartholomew, 1984). All these species have terminal flowers which are sessile and white; bracteoles and sepals are not differentiated, coriaceous; ovaries 3-locular; styles 3-5. Therefore the species should be classified into Sect. Oleifera Hung T. Chang. The main similarities and differences between $C$. hatinhensis with $C$. gauchowensis, C. oleifera, C. sasanqua, and C. vietnamemsis are summarized in Table 2.

\section{Acknowledgments}

The authors would like to express their sincere thanks to Mr. Hoang Van Hoan and Mr. Le Van Toan who provided valuable information leading to the discovery of those species. We are also grateful for the support provided through the JSPS KAKENHI Grant Number JP16K07239, Japan.

\section{Conflict of Interest}

Authors declare that there is no conflict of interest.

\section{Literature Cited}

Chang, H. T. \& B. Bartholomew. 1984. Camellias. B.T. Bastford Ltd., London, $211 \mathrm{pp}$.

Dung, L. V., L. Anna, N. T. Hanh and N. T. Lieu. 2016. Camellia thuongiana: a new yellow Camellia species from Vietnam. Dalat University Journal of Science 6: 338-344.

Gao, J., R. P. Clifford, Y. Q. Du. 2005. Collected species of the genus Camellia: an illustrated outline. Zhejiang Science and Technology Press, Guangzhou, 302 pp.

Ho, P. H. 1999: Theaceae. In Cây cỏ Việt Nam [An illustrated flra of Vietnam], Vol. 1. Pham-hoang, H. (ed.), Youth Publishing House, Ho Chi Minh City. Pp. 412-434. (in Vietnamese with English summary)

IUCN. 2011. International Union for Conservation of Nature, Red List Categories and Criteria, Version 3.1. Retreived Mar. 2, 2011, available from http://www.iucnredlist.org.

Ming, T. L. and B. Bartholomew. 2007. Theaceae. In Flora of China. Vol. 12. Hippocastanaceae through Theaceae. Wu, Z.Y., P. H. Raven and D. Y. Hong (eds.), Science Press, Beijing and Missouri Botanical Garden Press, St. Louis, MO. Pp. 366478.

Ninh, L. N. H. and L. V. Dung. 2016. General information about the Yellow Camellia species in Vietnam. In Proceedings of Dali International Camellia Congress, Dali, Yunnan, China.

Ninh, T. 2002. Biodiversity of the genus Camellia of Vietnam. International Camellia Journal 34: 80-88.

Ninh, T. and L. V. Dung. 2012. Camellia dalatensis: a new species and precious gene should be conserved. VNU Journal of Science, Natural Sciences and Technology 28(2S): 34-36.

Ninh, T. and L. V. Dung. 2013. Camellia dilinhensis: a new species from Vietnam. In Proceedings of the 3rd International Academic Forum on Yellow Camellias. International Camellia Society. Li, J. Y., Z. H. Li, Y. J. Luo and Z. Q. Fan (eds.), Nanning. P. 79.

Ninh, T. and L. T. H Ninh. 2015. A new yellow Camellia species from North Vietnam. International Camellia Journal 47: 3639.

Orel, G. and P. G. Wilson. 2010. Camellia luteocerata sp. nov. and a new section of Camellia (Dalatia) from Vietnam. Nordic Journal of Botany 28: 280-284.

Orel, G. and P. G. Wilson. 2012. Camellia cattienensis: a new species of Camellia (sect. Archaecamellia: Theaceae) from Vietnam. Kew Bulletin 66: 565-569.

Orel, G., P. G. Wilson, A. S. Curry and L. H. Truong. 2012. Camellia inusitata (Theaceae), a new species forming a new section (Bidoupia) from Vietnam. Edinburgh Journal of Botany 69: 347-355.

Orel, G., P. G. Wilson, A. S. Curry and L. H. Truong. 2013. Camellia oconoriana (Theaceae), a new species from Vietnam. Edinburgh Journal of Botany 70: 439-447.

Orel, G., P. G. Wilson, A. S. Curry and L. H. Truong. 2014a. Four new species and two new sections of Camellia (Theaceae) from Vietnam. Novon 23: 307-318.

Orel, G., P. G. Wilson and L. H. Truong. 2014b. Camellia curryana and C. longii spp. nov. (Theaceae) from Vietnam. Nordic Journal of Botany 32: 42-50.

Sealy, J. R. 1958. A revision of the genus Camellia. The Royal Horticultural Society, London, $239 \mathrm{pp}$.

Luu, H. T., V. D. Luong, Q. D. Nguyen and T. Q. T. Nguyen. 2015. Camellia sonthaiensis (Theaceae), a new species from Vietnam. Annales Botanici Fennici 52: 289-295.

Vu Quang National Park Management Board. 2014. Planning for conservation and development of Vu Quang National Park 2015-2020. The Author. (in Vietnamese) 